\title{
NOTES
}

\section{PERMISSIVE JOINDER AS A SUBSTITUTE FOR EXCLUDING EVIDENCE THAT DEFENDANT IS INSURED}

A PLAINTIFF is almost universally forbidden to inform the jury, as an independent fact, that a defendant is insured. ${ }^{1}$ The technical ground for exclusion is irrelevancy. ${ }^{2}$ Underlying the rule, however, is the assumption that disclosure will prejudice the jury in its determination of liability and in its award of damages. ${ }^{3}$ For this very reason, plaintiffs persistently strive to convey the fact of insurance at some stage of the proceedings. Their attempts are a fertile source of objections in the courtroom, and of ten result in mistrials and reversals. ${ }^{4}$ Almost without exception, courts hold that a deliberate reference to insurance is grounds for a new trial, and many courts extend the rule to cases where the reference is apparently inadvertent."

The extensive litigation engendered by the rule seems wasteful in view of the great variety of devices available for circumventing it. It is probably a rare case in which the defendant is insured and the jury is not informed of that fact. ${ }^{6}$ The technique most widely employed is to examine the juror's on voir dire regarding their interest in the defendant's insurance company.

1. 2 Wigniore, Evidence $\$ 282 a$ (3d ed. 1940). Today the rule of non-disclosure applies in every state unless the insurance company can be made a party to the action. Nebraska is the only state ever to have repudiated this rule by judicial decision. Jesstup v. Davis, 115 Neb. 1, 211 N.W. 190 (1926). And even in that state the defection was shortlived, for in Fielding v. Publix Cars, 130 Neb. 576, 265 N.W. 726 (1936), the Nebraska Supreme Court returned to the original rule.

2. Courts hold that the fact that a person carries insurance does not tend to show a generally reckless disposition on his part. But the carrying of insurance may be held relevant if shown to have influenced defendant's behavior on the specific occasion in isstuc. E.g., Herschensohn v. Weisman, 80 N.H. 557, 558, 119 Atl. 705 (1923) (defendant had been cautioned about his driving shortly before the accident; his reply, "Don't worry; I carry insurance for that," held properly admitted).

3. Sec International Co. v. Clark, 147 Md. 34, 42, 127 Atl. 647, 650 (1925) ; LeMny v. Young, 217 S.W.2d 862, 866 (Tex. Civ. App. 1949) ; Highway Express Lines v. Fleming, 185 Va. 666, 672, 40 S.E.2d 294, 297 (1946). See also Wigmore, Evivence $\$ 282 \mathrm{a}$ (3d ed. 1940).

4. See Notes, 28 A.L.R. 516 (1924); 56 A.L.R. 1418 (1928); 74 A.L.R. 849 (1931); 95 A.L.R. 388 (1935); 105 A.L.R. 1319 (1936). See also note 24 infra.

5. Nickell v. Stewart, $291 \mathrm{Ky} .4,163$ S.W.2d 39 (1942) ; Gerry v. Neugebauer, $\$ 3$ N.H. 23, 136 Atl. 751 (1927). The rule applies to inadvertent references by counsel as well. William Cameron Co. v. Downing, 147 S.W.2d 963 (Tex. Civ. App. 1941) (questions by plaintiff's counsel referring to one of defendant corporation's employces as an "adjuster," held prejudicial). The rule may provide a valuable device to an unserupulous attorney who sees that his case is going badly. By merely coaching one of his witnesses to make an apparently inadvertent reference to insurance on cross-examination, he could, if the ruse were undetected, thereby obtain a new trial.

6. See Note, 20 CorNeli L.Q. 110, 112 (1934). 
Practically all states permit such questioning in some form, 7 on the theory that a juror's interest in that company might infuence his verdict. ${ }^{8}$ This is obviously anomalous, because the basis of the non-disclosure rule is that jurors should remain ignorant of an insurer's interest in the case.

In addition to voir dire questioning, the fact of insurance is admissible when it bears on a material issue or affects credibility of witnesses. Thus, insurance may be revealed if it forms part of an admission of liability, ${ }^{10}$ or if it tends to prove the master-servant relation, ${ }^{11}$ or to establish ownership

7. Most courts hold that voir dire questioning regarding jurors' interest in insurance companies must be made in "good faith." But "good faith" is a phrase of many meanings. The trend of recent decisions is to require some form of preliminary inquiry, such as a conference with the judge, out of the jury's hearing, at which plaintiff's counsel inquires of defendant's counsel whether defendant is insured. If in preliminary inquiry of this lind it is found that defendant is not insured, questions concerning insurance are not allowed on voir dire. Henry v. Tinsley, 218 S.W.2d 771 (Mo. App. 1949); Safeway Cab Service Co. v. Alinor, 180 Okla. 448, 449, 70 P.2d 76, 78 (1937). A few states further require that the plaintiff show a "reasonable probability" that some prospective juror is interested in defendant's insurance company. Wheeler v. Rudek, 397 III. 438, 442, 74 N.E.2d 601,603 (1947). But in many states the question of what constitutes "good faith" is leit largely to the trial judge, with no definite standards to guide him. See Raines v. Wilson, 213 Iowa 1251, 239 N.W. 36 (1931) ; Stalcup v. Ruzic, 51 N.11. 377, 185 P.2d 29S (1947).

Some courts permit jurors to be asked whether they are interested in any insurance company even when the defendant is not insured. Roselle v. Beach, 51 Cal. App.2d 579, 125 P.2d 77 (1942) ; Dowd-Feder v. Truesdell, 130 Ohio St. 530, 200 N.E. 762 (1936), 10 U. of CIN. L. REv. 315.

8. Courts differ as to whether such interest, if it exists, is ground for challenge for cause or merely provides a basis for peremptory challenge. See, e.g., Anderson v. Todd Shipyard Corp., 63 F. Supp. 229 (S.D.N.Y. 1945) (if juror is employed by the insurance company interested in the case, challenge for cause; if employed by some other insurance company, no challenge for cause); Tatum v. Croswell, 178 Ga. 679, 174 S.E. 140 (1934) (challenge for cause) ; Mortrude v. Miartin, 185 Iowa 1319, 1332, 172 N.WW. 17, 22 (1919) (dictum indicating that it is basis for peremptory challenge only); Alurphy v. Cole, 338 Mo. 13, 88 S.W.2d 1023 (1935) (challenge for cause).

9. The anomaly has been pointed out by MfCConarrck, Cases ON Errrexce, $530 \mathrm{n}$. (2d ed. 1948). The fact that voir dire questioning is permitted is itself an admission that the rule of non-disclosure does not work. See Pavilonis v. Valentine, 120 Ohio St. 154, 159, 165 N.E. 730, 731 (1929), in which the court said, "The assumption that but for the voir dire examination the jurors would not have suspicioned that a casualty insurance company was interested in the case reflects upon the intelligence of the jurors."

10. Jackson v. Ellis, 213 Ark. 826, 828, 212 S.W.2d 715, 717 (1948) (defendant stated following the accident, "Don't worry: we are fully covered by insurance and I'm taling all the blame.") ; Reid v. Owens, 98 Utah 50, 60, 93 P.2d 6S0, 685 (1939) (defendant stated, "My boy is careless. . . . If you won't prosecute . . . our boy, we will do all we can to help you get that $\$ 5,000$ insurance.") ; Zigler v. Kinney, 250 Wis. 338, 27 N.W.2d 433 (1947) (defendant stated that the accident was his fault and that he had insurance). Contra: Crapson v. United Chatauqua Co., 27 S.W.2d 722, 724 (MFo. App. 1930) (defendant's manager stated, "I will admit we are in the wrong. I will get you all we can out of the insurance company.").

11. E.g., Barg v. Bousfield, 65 Minn. 355, 68 N.W. 45 (1896) (fact that defendant's insurance policy covered plaintiff tended to show that plaintiff was employee of defendant); 
of the instrumentality causing the injury, ${ }^{12}$ or to show bias or interest on the part of a witness. ${ }^{13}$ When the defendant argues his inability to pay a large judgment, courts may consider that the subject of insurance has been raised, ${ }^{14}$ and may then allow comment by the plaintiff. ${ }^{15}$ And a further opportunity for the jury to learn of insurance is afforded by the practice of some courts to hold that inadvertent references to insurance are cured by striking the testimony and instructing the jury to disregard it. ${ }^{10}$ In these and myriad other ways ${ }^{17}$ the jury may be informed in so many words that an insurance company is in the picture.

Boten v. Sheffield Ice Co., 180 Mo. App. 96, 166 S.W. 883 (1914) (same); Biggins v. Wagner, 60 S.D. 581, 245 N.W. 385 (1932) (policy tended to show that driver of truck was defendant's employee); Delamar \& Allison v. Ward, 184 Ark. 82, 41 S.W.2d 760 (1931) (fact that defendant made deduction for insurance from truck driver's pay tended to prove that latter was employee rather than independent contractor).

12. E.g., Gayheart v. Smith, 240 Ky. 596, 42 S.W.2d 877 (1931) (ownership of taxi involved in accident); Davis v. North Carolina Shipbuilding Co., 180 N.C. 74, 104 S.E. 82 (1920) (ownership of the plant where plaintiff was injured); Harper v. Highway Motor Freight Lines, 89 S.W.2d 448 (Tex. Civ. App. 1935) (ownership of truck).

13. E.g., Ingalls Shipbuilding Corp. v. Trehern, 155 F.2d 202 (5th Cir. 1946) (insurance company's adjuster); Kiewert v. Balaban \& Katz Corp., 251 Ill. App. 342 (1929) (insurance company's doctor who examined plaintiff); Scholte v. Brabec, $177 \mathrm{Minn} .13$, 224 N.W. 259 (1929) (insurer's doctor who testified as expert witness).

14. Clark-Pratt Cotton Mills Co. v. Bailey, 201 Ala. 333, 77 So. 995 (1918); Stilson v. Ellis, 208 Iowa 1157, 225 N.W. 346 (1929), 15 Iowa L. REv. 228 (1930); cf. M. O'Connor \& Co. v. Gillaspy, 170 Ind. 428, 83 N.E. 738 (1908) (plaintiff alleged medical expenses and defendant introduced evidence to show that he had defraycd them; held proper for plaintiff to ask questions designed to show that the insurer had reimbursed defendant). Contra: D \& H Truck Line v. Lavalee, 7 S.W.2d 661 (Tex. Civ. App. 1928). Strictly speaking, insurance has no more relevance when defendant raises it than when plaintiff does, but courts are more lenient with a defendant because the rule sceks to prevent prejudice against him.

When defendant's insurance protection is inadequate, he will often want to inform the jury of that fact, but it is generally held that he may not do so. Fox v. Missouri Jobbing House, 32 S.W.2d 130 (Mo. App. 1930); Piechuck v. Magusiak, 82 N.H. 429, 135 Atl. 534 (1926). But cf. Stehouwer v. Lewis, 249 Mich. 76, 227 N.W. 759 (1929) (where plaintiff had made inquiries on voir dire, defendant was allowed to deny that he carried insurance); Whitman v. Carver, 337 Mo. 1247, 88 S.W.2d 885 (1935) (plaintiff latd testified that defendant had stated he was insured; defendant was allowed to deny this statement and to add that he did not know if he was covered by insurance or not).

15. E.g., Feore v. Trammel, 212 Ala. 325, 102 So. 529 (1924); Huhn v. Ruprecht, 2 S.W.2d 760 (Mo. 1928) ; Rice v. Garrett, 194 S.W. 667 (Tex. Civ. App. 1917).

16. Lowe v. Poole, 235 Ala. 441, 179 So. 536 (1938); Trout v. Talerico, 237 Iowa 285, 21 N.W.2d 672 (1946); Trafamczak v. Anys, 320 Mich. 653, 31 N.W.2d 832 (1948). See also note 5 sipra.

17. E.g., Andrus v. Hall, 93 Colo. 526, 27 P.2d 495 (1933) (in reply to question on cross-examination, defendant indicated presence of an insurance company by testifying that he had first met his counsel only one day before trial); Guarnaccia v. Weisenski, 130 Conn. 20, 31 A.2d 464 (1943) (photostatic copy of an accident report to the Motor Vehicle Commissioner referring to insurance, held properly admitted); Chapman v. Independent Laundry Co., $38 \mathrm{Ga}$. App. 424, 144 S.E. 127 (1928) (plaintiff permitted to show that 
Aside from direct references to insurance during the trial, other factors may suggest it to the jury. Jurors may recognize defendant's attorney as one who frequently represents insurance companies. ${ }^{13}$ Especially in small communities, a juror may personally know that defendant carries insurance. Newspaper accounts of the accident or of the suit may disclose the fact. ${ }^{19}$ The jury may know that in the case of some defendants, insurance is required by law. ${ }^{23}$ Most important of all, the jury may simply assume, ${ }^{21}$ in the absence of any information, that the defendant is insured. The question most frequently arises in automobile accident cases, and it is common hnowledge today that a large percentage of automobile owners are insured against liability. ${ }^{22}$

With so many devices available for suggesting insurance to the jury, it is evident that the protection the exclusionary rule supposedly affords is

defendant had assigned his right of action on counterclaim to his insurance company); Gegan v. Kemp, 302 Mfich. 218, 4 N.W.2d 525 (1942) (witness allowed to testify that his prior inconsistent statement was prepared for his signature by an insurance adjuster).

18. See Nilles, The Right To Intcrrogate Jurors Itith Reference To Insurance In Negligence Cases, 3 DAE. L. REv. 406, 408 (1931), in which the author, a practicing attorney, points out that "lawyers, at least in this part of the country [North Dalsota], are thoroughly familiar with the antecedents of prospective jurors. . ." The converse might also be true in such localities. See also Stotts v. Love, 184 S.W.2d 308, 309 (Tex. Civ. App. 1944) (juror testified, "Some of them, I think, said he [attorney for defendant] was probably hired by the year by the insurance company."). Jurors are especially likely to recognize defendant's attorney as a representative of an insurance company where the same jurors are used throughout a term and thus become familiar with the various attorneys appearing in court.

19. In Hoffecker v. Jenkins, 151 F.2d 951, 953 (4th Cir. 1945), an article had appeared in a local newspaper stating that it was "reported the defendants were covered by liability" insurance." The trial court instructed the jury to disregard it; held no error on appeal.

20. See Barrington v. Duncan, 140 Tex 510, 516, 169 S.W.2d 462, 464 (1943) in which the court states, "It is shown that the jury was told by one of its members, who was himself a truck driver, that the Barringtons had to have insurance in order to get a permit to operate their trucks. ..." Almost all states have compulsory insurance laws for public carriers and certain other types of commercial vehicles. See Comment, 42 Yas: L.J. 1103 (1933) ; Note, 39 ILL. L. REv. 81 (1944). Miassachusetts requires insurance as a prerequisite to registration of any motor vehicle. 3 MAss. Am. Inws c.90, $\$ \$ 34 \mathrm{~A}-34 \mathrm{~J}$ (1946).

21. That jurors assume insurance is not entirely a matter of conjecture. See, c.g., Kellerher v. Porter, 189 P.2d 223, 230 (Wash. 1948) (after verdict, juror testified, "There was quite a bit of talk about insurance during the discussion. . . I I mentioned something like, 'the Porters must have been insured." "); Sutherland v. Keene, 203 S.W.2d 917, 922 (Tenn. App. 1947) (juror testified that another juror said, "What are you vorrying about? The insurance company is going to pay it anyway."); Stotts v. Love, 184 S.W.2d 308, 310 (Tex. Civ. App. 1944) (juror testified, "Yes it [insurance] was mentioned. . ...").

22. The National Bureau of Casualty Underwriters states that figures on the percentage of insured automobiles in the United States are unobtainable. Communication to the Yale Law Journal, dated April 17, 1950, in Yale Law Library. In some states, however, the percentage of insured vehicles is very high. In New York, for example, from $85 \%$ to $90 \%$ of all automobiles are insured. Buffalo Evening News, Jan. 11, 1950, p. 49, col. 5; New York Herald Tribune, Feb. 8, 1950, p. 2, col. 4. 
largely illusory. The ever increasing mass of reported decisions ${ }^{23}$ on the subject indicates that the rule serves only to promote quibbling in the courtroom, protracted litigation, and repeated reversals and mistrials. For if the defendant is insured, it is a singularly unresourceful plaintiff who cannot find a legitimate way of suggesting that fact to the jury. And if the defendant is uninsured, the jury in its ignorance may assume the contrary and the rule of non-disclosure prevents his informing them of the actual situation. ${ }^{24}$

Piecemeal remedies offer no solution. Courts might allow free comment by both sides once there has been legitimate disclosure of insurance during the trial. But this scheme ignores the fact that when nothing is said about insurance, juries may often assume that the defendant is insured. Jurors might be examined regarding their interest in insurance companies at the beginning of the term rather than after they have been assigned to particular cases. ${ }^{25}$ But questioning of this kind would still suggest insurance; and the opportunities for disclosure during trial would be as great as before.

The futility of the present rule and the inadequacy of any piecemeal remedies suggests that the only satisfactory solution would be a statute permitting joinder ${ }^{26}$ of the insurer as a defendant and allowing unrestricted comment on the question of insurance. Once the insurance company has been made a joint defendant, not only the issue of fault but all issues arising between the insurer and assured would be decided in a single proceeding. Thus the insurance company could plead its customary defenses, such as lapse, non-coverage, and lack of cooperation. ${ }^{27}$ The statute would further

23. For example, the five A.L.R. annotations cited in note 4 supra cover a total of 211 pages. In addition, A.L.R. lists over 400 cases on the subject since the latest annotation. A.L.R. Blue Book of Suppleasental Decisions.

24. Of course, a few of the disclosure devices available to the plaintiff may also be employed by the defendant. And insofar as the uninsured defendant may utilize them, he can avoid the jury's prejudicial assumption that he is insured. Sce note 14 supra. If joint defendants are involved and only one is insured, the uninsured defendant may not disclose his lack of coverage even though questions have been asked on voir dirc regarding insurance. Malone v. Small, 291 S.W. 163 (Mo. App. 1927). For a discussion of the plight of the uninsured defendant, see Note, 38 W. VA. L.Q. 362 (1932).

25. For various proposals of this type, see Hawkins, The Juror's Good Faith in Issuc, [1948] Ins. L.J. 7; Comment, 43 IlL. L. Rev. 650 (1948); Notes, 52 Hanv. L. REv. 166 (1938) ; 43 Mich. L. Rev. 621 (1944); 17 Minn. L. Rev. 299 (1933); 87 U. of PA. L. REv. 234 (1938).

26. In references to existing statutes permitting joinder of the insurer, see note 32 infra, commentators have often erroneously used the term "compulsory joinder." A more descriptive term is "permissive joinder."

27. Although such a statute would preserve all existing defenses, it would not reinstate any defenses previously abolished by other statutes such as compulsory insurance and financial responsibility laws. For discussion of the defenses and the changes made in them by statute, see Billings, Impact Of Financial Responsibility On Automobile Liability Insurance, [1949] Ins. L.J. 871; Durland, Blood And Marital Relationships Under The Cooperation Clause, [1949] Ins. L.J. 3; Steensland, Motor Vehicle Safely Responsibility Act, [1947] WIs. L. REv. 146; A Guide To The Automobile Policy, [1949] Iss. L.J. 867; 
allow the company to amend the pleadings at any time prior to final argument, in order that the insurance company could interpose the defense that the assured had failed to cooperate during the trial. When there are no issues between insurer and assured, the judge would instruct the jury that if it finds the assured liable it must return a verdict against both defendants. If there are any issues of law between insurer and assured the judge would decide these before submitting the case to the jury. If there are issues of fact between insurer and assured, the judge would instruct the jury that it could return a verdict against neither defendant, against the assured alone, or against both defendants. ${ }^{28}$ The statute should permit joinder ${ }^{2}$ only if proper service of process has been had upon the assured. Otherwise, since most insurance companies can be served in many jurisdictions, plaintiff would have wide latitude in shopping for a favorable forum. . $^{2}$ Nevertheless, the statute should expressly authorize full disclosure and comment regarding the existence or lack of insurance in every case, regardless of whether an insurer has been joined as a defendant. ${ }^{31}$

The only states with statutes similar to the one proposed are IVisconsin and Louisiana.32 While for the most part satisfactory, these statutes are deficient in some respects. They permit a plaintiff to make an insurance company a defendant even in cases where service of process cannot be had upon the assured, thus allowing a plaintiff to seek a jurisdiction with a reputation for generous verdicts. ${ }^{33}$ Neither statute makes any provision for

Comment, 28 Irt. L. Rev. 688 (1934); Note, 46 HARv. L. Rev. 1325 (1933). See also note 20 supra.

28. Since the insurer is liable only if the insured is liable, the judge would instruct the jury that no verdict could be returned against the insurance company alone.

29. The statute should be worded to permit joinder of the insurer of any party who may be subject to liability. This would include the insurer of a plaintiff against whom a counterclaim has been filed. And see Gray v. Hartford Accident \& Indemnity Co., 31 F. Supp. 299 (W.D. La. 1940) (defendant permitted under permissive joinder statute to join as defendants driver of car in which plaintiff was riding and driver's insurer).

30. The plaintiff, in looking for his favorable forum, would, of course, be limited to those states having permissive joinder statutes.

31. To restrict discussion or disclosure by any "good faith" or similar rule would only leave open avenues for further litigation concerning the exact definition of "good faith," and therefore retain one of the greatest evils of the present rule. Repetitious disclosure and counsel's comments regarding insurance, however, would always be subject to the trial court's power to exclude superfiuous and cumulative testimony.

32. Wis. Stat. $\$ 260.11$ (1947); LA. Gen. Stat. $\$ 4014.45$ (Dart Supp. 1949). For discussion of the problems arising under these statutes, see Coleman, The Defendant Irsurance Company In Autonobile Cases, 19 ILARQ. L. Rev. 1 (1934); Leigh, Dircet Aetions Against Liability Insutrers, [1949] INs. L.J. 633; MIcKenna, Joining The Instrer And Insured Iib Automobile Cases, 17 MAARQ. L. REv. 114 (1933); Note, 20 CuRrietr L.Q. 110 (1934). A few states have interpreted their compulsory insurance statutes to permit joinder of insurers in those cases where the defendant is required by law to carry insurance. See Note, 39 ILl. L. Rev. S1, 83 (1944). See also note 20 supra.

33. The Louisiana statute provides expressly for a suit against the insurer alone. LA. GEN. STAT. $\$ 4014.45$ (Dart Supp. 1949). The Wisconsin statute, while not explicit, has 
disclosure and comment in cases where an insurer has not been joined. ${ }^{34}$ The Wisconsin statute, instead of requiring that all issues be settled in a single trial, gives the court unlimited discretion to direct a separate trial on any issues arising between insurer and assured. ${ }^{35}$ Finally, this statute permits joinder of an insurer only in automobile accident cases.

It is not at all certain that there would be any marked increase in the size of verdicts if free disclosure were permitted. The trial court could instruct the jury that its verdict may be set aside if the damages awarded are unreasonable or if the verdict is against the weight of the evidence. ${ }^{30}$ The court in its charge and defendants' counsel in argument could point out to the jury that excessive verdicts will have the effect of raising insurance rates generally. ${ }^{37}$ Defendants could always argue to the jury that plaintiff is trying

been construed by the courts to permit such suits. Wis. Stat. $\$ 260.11$ (1947). Sce, c.g., Kujawa v. American Indemnity Co., 245 Wis. 361, 14 N.W.2d 31 (1944); Oertel v. Williams, 214 Wis. 68, 251 N.W. 465 (1934).

Experience under the Louisiana statute demonstrates some of the unexpected results of permitting a suit against the insurer alone. See, e.g., Casualty Co. v. Soileau, 167 F.2d 767 (5th $\mathrm{Cir}$. 1948) (necessary diversity for federal jurisdiction held established despite the fact that both plaintiff and assured were residents of Louisiana); Harvey v. New Amsterdam Casualty Co., 6 So.2d 774 (La. App. 1942) (plea of coverture is a personal defense and is not available to a husband's insurer in a suit by wife) ; Rome v. London \& Lancashire Indemnity Co. of America, 169 So. 132 (La. App. 1936) (defense that City Park Improvement Association was acting in a governmental capacity held personal to the association and not available to its insurer).

34. Since passage of the act, however, the Wisconsin courts have been more liberal in allowing references to insurance. Compare Doepke v. Reimer, 217 Wis. 49, 258 N.W. 345 (1935), with Pawloski v. Eskofski, 209 Wis. 189, 244 N.W. 611 (1932). But in the Doepke case, supra at 55, 258 N.W. at 347, the Wisconsin Supreme Court stated that the statute was not intended to justify "invidious insinuations" against the insurer or questions asked solely for the purpose of "unduly emphasizing" insurance.

The absence of reported decisions in Louisiana on the subject of disclosure is probably explained by the civil law rules prevailing in that state which regard a jury verdict as merely advisory and which permit review of questions of fact on appeal. As a restult, it has been estimated that approximately $98 \%$ of contested civil cases are tried before a judge only, and hence there is no problem of jury prejudice. Communication to the YALE LAW Journal from Mr. Thomas W. Leigh, Attorney, of Monroe, Louisiana, dated April 18, 1950, in Yale Law Library.

35. A model statute, while preserving the judge's usual discretion to sever isstes, would specifically prohibit severance of the insurance issues where the sole ground for severance is the claim that evidence of insurance would prejudice defendants.

36. The trial court could likewise order a remittitur if it regards the verdict as excessive. A remittitur forces the plaintiff to accept either a new trial or a reduced judgment. These devices will always be available to relieve any harsh effects of a permissive joinder statute in exceptional cases.

37. See Triangle Cab Co. v. Taylor, 190 S.W.2d 755, 762 (Tex. Civ. App. 1945) (jury foreman testified that some juror said that "[h]e sure bet insurance rates for taxis would sure take a jump after this case was over"). Jurors will probably be increasingly concerned about the effect of verdicts on automobile insurance rates since a progressively larger percentage of automobile owners, including jurors, carry such insurance. Sce note 22 supra. 